\title{
過酸化ポリピロール/ポリビニルピロリドン膜修飾カーボン ペースト電極を用いるフェノール測定の基礎検討
}

\author{
陳 智 棟 ${ }^{1}$, 北條 正司 ${ }^{\circledR 2}$
}

\section{1 緒言}

フェノールは人体に有害な化学物質の一つである。開発 途上国などでは製紙，医薬品，農薬やコークスなどの製造 に伴い，自然環境にフェノール污染がもたされている。フ エノールに污染された飲料水を長期に渡って飲用すると， 人体に頭痛, 精神的な不安, 貧血などの症状を引き起こす. 通常, フェノールの測定法には, 分光光度法やクロマトグ ラフ法が利用されることが多( ${ }^{1) ~ 3) . ~ し か し ， こ の よ う な ~}$ 方法では分析に手間がかかり，その場分析は適用できな い. Anh ら ${ }^{4)}$ は，チロシナーゼ（tyrosinase）をイオン選択 性電界効果型トランジスター（ISFET）表面に修飾したフ エノールのセンサーを開発した。このセンサーはフェノー ルに対し, せいぜい $1.5 \times 10^{-4} \mathrm{M}$ 程度の検出限界であり, その上, 寿命が短いことが問題として残っていた. チロシ ナーゼのほかに, ペルオキシダーゼを用いるバイオセンサ 一によるフェノールの分析法が研究されている ${ }^{5)}$. 一方, 吸着ストリッピングボルタンメトリーによるフェノールの 定量法がいくつか報告されている. 例えば, パラフィンで 修飾したカーボンペースト電極的や Nafion 修飾したグラ ッシーカーボン電極〉によるものなどである.

本研究では過酸化ポリピロール/ポリビニルピロリドン で修飾したカーボンペースト電極を作製して，フェノール 測定に応用した。この修飾電極は簡単に作製でき，また， 電極表面を更新しやすいことから廃水中のフェノール測定 への適用に向け，基礎検討を行った。ここで，フェノール 類の（陰イオン）のサイクリックボルタンメトリー挙動は, 可逆的 1 電子酸化であり, 生成物は, 通常の電気化学的 手法の時間スケールに打いては十分に安定なフェノキシラ ジカルであるとされている8)ことを述べて扔く.

\section{2 実験}

\section{$2 \cdot 1$ 試 薬}

ピロール（Py）は東京化成の特級品を用い, ポリビニル

\footnotetext{
${ }^{1}$ 中国江蘇工業学院化学工程系: 213164 中国江蘇省常州市大学城 2 高知大学理学部物質科学科: $780-8520$ 高知県高知市曙町 2-5-1
}

ピロリドン (PVP) は和光純薬の特級品（分子量 100 万〜 150 万）を用いた。他の試薬はすべて特級品を使用し，水 はイオン交換水を用いた。

\section{$2 \cdot 2$ 装 置}

サイクリックボルタンメトリーにおいて，作用極は $\mathrm{OPPy} / \mathrm{PVP}$ (過酸化ポリピロール/ポリビニルピロリドン) で修飾したカーボンペースト電極 (ID $1.6 \mathrm{~mm}$ ), 対極に は白金線（直径 $1 \mathrm{~mm}$, 長さ $8 \mathrm{~cm}$ ), 参照電極には飽和 銀一塩化銀電極を用いた. 測定には天津藍力科製のポテン ショスタットLK98BII を用いた。

\section{$2 \cdot 3$ 電極の修飾}

カーボン粒子（日本カーボン，粒径 $30 \mu \mathrm{m}$ ） とパラフィ ン（5.6:1）をよく混合して, カーボンペースト電極を作 製した. 次に, この電極上に, OPPy/PVP 膜を修飾する. 修飾方法としては，先ず， $0.1 \mathrm{M} \mathrm{Py}, 0.2 \mathrm{~g} / \mathrm{L}$ PVP 及び $0.1 \mathrm{M} \mathrm{H}_{2} \mathrm{SO}_{4}$ を含む水溶液中において, カーボンペースト 電極を $0.0 \sim+1.2 \mathrm{~V}$ の範囲で $60 \mathrm{mV} / \mathrm{s}$ の掃引速度で 35 回繰り返し電位掃引（サイクル）させ, ポリピロール/ポ リビニルピロリドン (PPy/PVP) 膜修飾したカーボンペー スト電極を作製した。PPy/PVPで修飾したカーボンペー スト電極を $0.1 \mathrm{M} \mathrm{NaOH}$ の溶液中で過酸化処理し, $\mathrm{OPPy} / \mathrm{PVP}$ 膜カーボンペースト電極を作製した ${ }^{9)}$.

OPPy 膜カーボンペースト電極の修飾方法は OPPy/PVP 膜カーボンペースト電極と同じであるが, 最初にカーボン ペースト電極を修飾する際に, PVPをPyの溶液中に添加 しないだけの違いがある。

\section{$2 \cdot 4$ 実験方法}

$\mathrm{OPPy} / \mathrm{PVP}$ 膜カーボンペースト電極を用いて, $0.1 \mathrm{M}$ $\mathrm{KCl}$ 溶液中のフェノールを開路濃縮した.フェノールを濃 縮した OPPy/PVP膜カーボンペースト電極は $\mathrm{pH} 10.0$ の リン酸緩衝液中でのアノーディックストリッピング法 （ASV）により，フェノールの定量分析に供した。特に断 りのないかぎり $25 \pm 11^{\circ} \mathrm{C}$ において測定を行い, 各測定ご とに，5分間窒素を通気し，溶存酸素を除去した. 


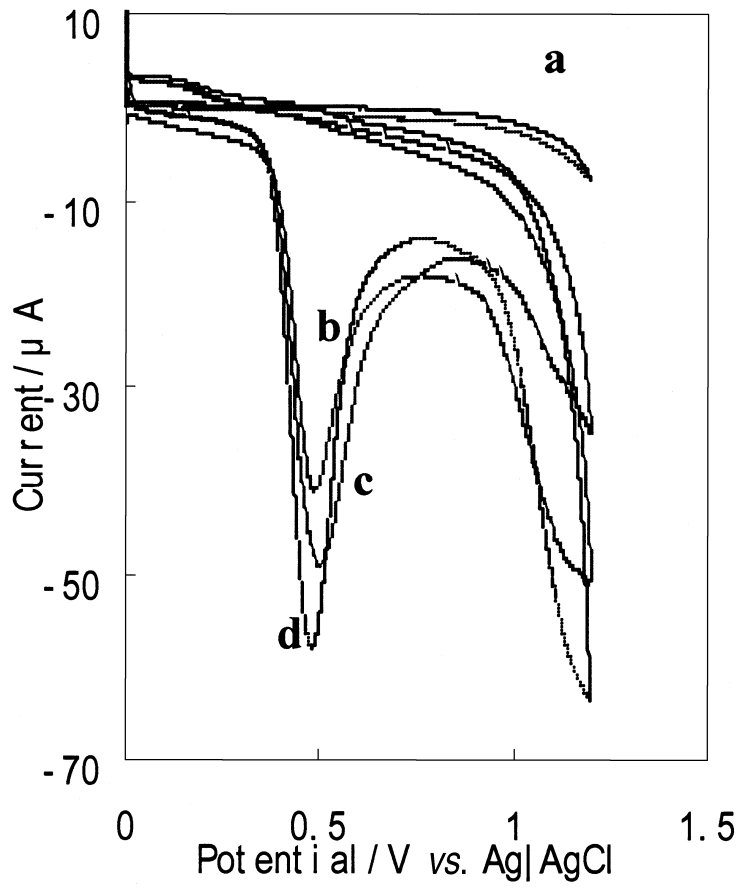

Fig. 1 Cycle voltammograms of $1.0 \times 10^{-3} \mathrm{M}$ phenol at a bare electrode (a), OPPy modified electrode (b), PVP modified electrode (c) and OPPy/PVP modified electrode (d) in $0.1 \mathrm{M} \mathrm{KCl}$

Preconcentration time: $10 \mathrm{~min}$, Scan rate: $60 \mathrm{mv} / \mathrm{s}$

3 結果と考察

\section{$3 \cdot 1 \quad \mathrm{OPPy} / \mathrm{PVP}$ 膜カーボンペースト電極上のフェノー ルの電気化学挙動}

サイクリックボルタンメトリーにより，カーボンペース 卜電極，PVP 修飾したカーボンペースト電極，OPPy膜カ ーボンペースト電極及び OPPy/PVP 膜カーボンペースト 電極について，フェノールの電気化学的挙動を調べた.

それぞれ 4 つの電極を使って $1.0 \times 10^{-3} \mathrm{M}$ のフェノー ルが溶存する $0.1 \mathrm{M} \mathrm{KCl}$ 溶液中に扔いて，開路 10 分間フ エノールを濃縮した。フェノールが濃縮された電極を $0.1 \mathrm{M}$ リン酸緩衝液（ $\mathrm{pH}$ 10.0）中に移し，サイクリック ボルタンメトリーを行った。未修飾カーボンペースト電極 上では，フェノールは $0.65 \mathrm{~V}$ に極微小な酸化電流を生じ たが，この結果から，未修飾カーボンペースト電極はフェ ノールを濃縮する能力が非常に低いことが分かった (Fig. 1a参照).

OPPy 膜カーボンペースト電極を用いると, Fig. 1bに 示すように， $0.48 \mathrm{~V}$ に酸化電流が生じた。この電流は未修 飾カーボンペースト電極上の電流より大きかった．この結 果は, OPPy 膜はフェノールに対して濃縮効果があること を示している. pH 6.0 に扔いては，フェノールは解離す ることなしに，主に分子状態で存在している（フェノール
の $\left.\mathrm{p} K_{\mathrm{a}}=9.98\right)$.フェノールは過酸化ポリピロール膜と水 素結合相互作用をすることにより，濃縮されやすくなると 考えられる。しかし，pH 10.0 のリン酸緩衝溶液中に执い ては, 濃縮されたフェノールが解離し (約 50\%), 陰イオ ンになるため, 電子密度の高い過酸化ポリピロール膜に排 斥され，フェノールが過酸化ポリピロール膜から出やすく なると思われる ${ }^{9)}$.このようにして，フェノールの酸化電 位は負側にシフトする。

PVPをカーボンペーストと混合したPVP 修飾カーボン ペースト電極を使用した場合は，Fig. 1cに示すように， フェノールは $0.53 \mathrm{~V}$ に酸化電流を生じた。この結果は PVPがフェノールに対して濃縮効果を示すことを意味し ている.PVP とフェノール間に水素結合が作用すること が報告されている ${ }^{10)}$. OPPy/PVP 膜が使用されたときに は, Fig. $1 \mathrm{~d}$ に示すように, フェノールは $0.48 \mathrm{~V}$ に酸化電 流を生じた。この $\mathrm{OPPy} / \mathrm{PVP}$ 膜電極上の電流値は OPPy 膜電極による電流值の 1.8 倍, PVP 修飾電極による電流值 の 1.4 倍であったが，このように電流值が大きいのは OPPy 膜と PVP の協同効果に起因すると考元られた。 $\mathrm{OPPy} / \mathrm{PVP}$ 膜カーボンペースト電極上，20〜 $120 \mathrm{mV} / \mathrm{s}$ の 掃引速度範囲に执いて, 掃引速度の増加に従って, フェノ 一ルの酸化電流が直線的に高くなった。この結果により, $\mathrm{OPPy} / \mathrm{PVP}$ 膜カーボンペース卜電極上のフェノールの酸 化が搪散によってではなく吸着効果にコントロールされる ことが示された。

\section{$3 \cdot 2$ PVP 濃度の影響}

電気化学的手法で，ポリピロール膜を作る際，膜の性質 を改善するために，よく PVP が用いられる ${ }^{11)}$. PVPがフ エノールに対する濃縮効果を持つことが分かったので, $\mathrm{OPPy} / \mathrm{PVP}$ 膜を作成する際に，PVP の使用量について検 討した. Fig. 2 に示すように, OPPy/PVP 膜カーボンペー スト電極上のフェノール酸化電流は PVP 濃度の増大に従 って，増加した．PVP の濃度が $0.2 \mathrm{~g} / \mathrm{L}$ のとき，電流值は 最大となり, 更にPVP の濃度が増加すると, 電流值は小 さくなった。しかし，PVP の濃度が $0.6 \mathrm{~g} / \mathrm{L}$ を超えると， 電流值はあまり変化しなかったそそれはPVP の濃度が高 くなると, $\mathrm{OPPy} / \mathrm{PVP}$ 膜の中の PVP 濃度が増ることによ り, 膜の電子伝達能力が低下し, フェノールの酸化電流も 小さくなると考えられる，以上の実験結果により，PVP の濃度として $0.2 \mathrm{~g} / \mathrm{L}$ を選んだ。

\section{$3 \cdot 3 \quad \mathrm{OPPy} / \mathrm{PVP}$ 膜厚さの影響}

$\mathrm{OPPy} / \mathrm{PVP}$ 膜の厚さはフェノールの酸化電流に大きな 影響を及ぼす。フェノール酸化電流值をカーボンペースト 電極の $(\mathrm{PPy} / \mathrm{PVP})$ 膜修飾液中の繰り返し電位掃引（サイ クル）回数（実験項 $2 \cdot 3$ を参照, OPPy/PVP 膜の厚さに 


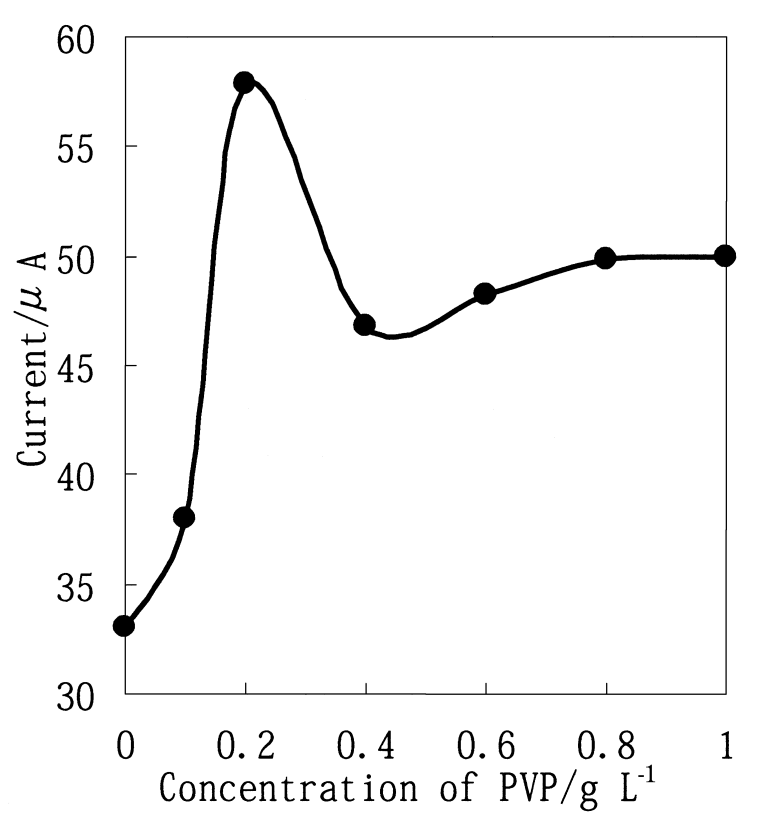

Fig. 2 Effect of the amount of PVP on the peak current of $1.0 \times 10^{-3} \mathrm{M}$ phenol

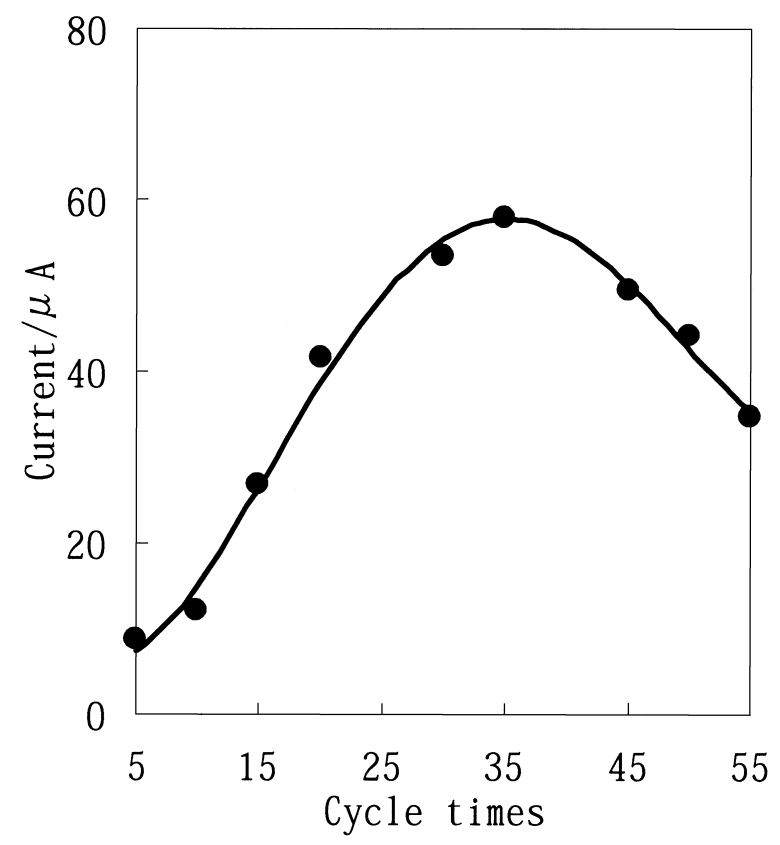

Fig. 3 Effect of the cycle times on the peak current of $1.0 \times 10^{-3} \mathrm{M}$ phenol

関係する）に対してプロットすると Fig. 3のようになっ た. 電位掃引の繰り返し (サイクル) 回数の増加に伴って, 電極はフェノールに対する濃縮能力が高くなり, フェノー ルの酸化電流が大きくなる. サイクル数 35 回のとき, 酸 化電流が最大となり, それ以上サイクル回数が増えると, フェノールの酸化電流が逆に小さくなった。これはサイク

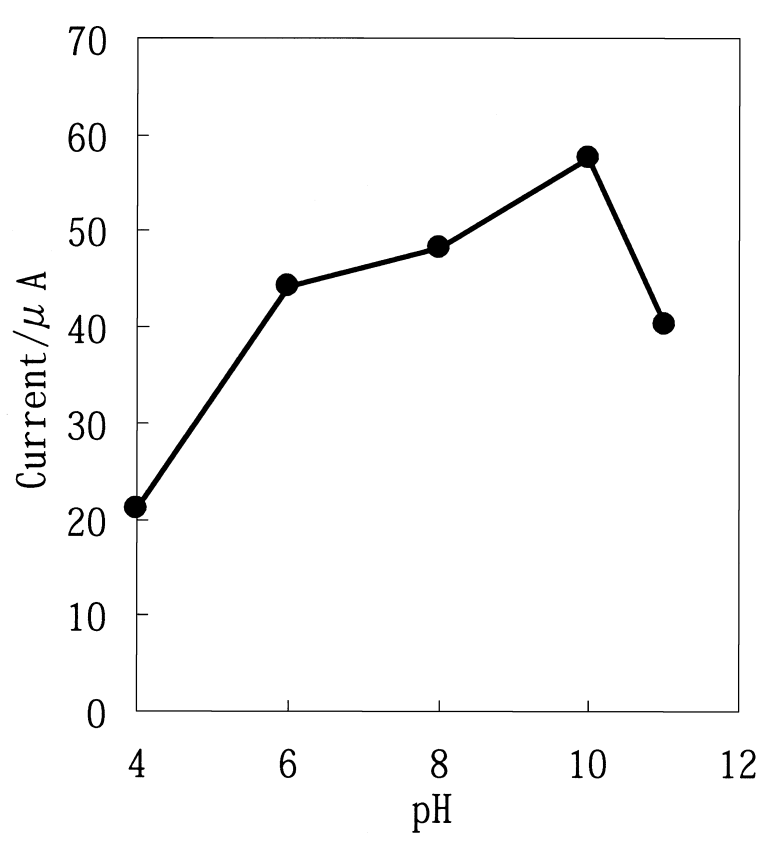

Fig. 4 Effect of the $\mathrm{pH}$ on the peak current of $1.0 \times$ $10^{-3} \mathrm{M}$ phenol

ル回数の増加により, 膜が厚くなることにより膜の電気抵 抗も増え, フェノールの酸化電流が小さくなるためである と考えられた。このため, カーボンペースト電極を修飾す る際に, サイクル回数は 35 回とした.

\section{$3 \cdot 4$ フェノール溶出液及び $\mathrm{pH}$ の選択}

フェノールを OPPy/PVP膜カーボンペースト電極に濃 縮させた後, それぞれ $0.1 \mathrm{M} \mathrm{KCl}, \mathrm{KNO}_{3}$ 又は $\mathrm{Na}_{2} \mathrm{HPO}_{4}$ 溶 液中において, フェノールの溶出電流を観測した.フェノ ールは 0.1 M の $\mathrm{Na}_{2} \mathrm{HPO}_{4}$ 溶液中で, 良好な電流ピークを 与え, また電流值は最大となった。このように陰イオン又 は $\mathrm{pH}$ の効果が示唆されたので, $\mathrm{pH}$ の影響を検討した. Fig. 4 に示すように, 溶出溶液の $\mathrm{pH}$ が 10.0 のとき, フ エノールの電流值は最大となった.フェノールの $\mathrm{p} K_{\mathrm{a}}$ は 9.98 であり, 溶出溶液の $\mathrm{pH}$ が 10.0 を超えると, 修飾電 極表面に濃縮されたフェノールは主にアニオンの状態で存 在（50\% 以上）することになり，OPPy膜中の過剩の負電 荷によって排斥されることにより，フェノールの酸化電流 が大きくなると考えられる. 同時にフェノールの酸化電位 も負にシフトした. 以上の理由から, 本研究ではフェノー ル溶出液として, $0.1 \mathrm{M} \mathrm{Na}_{2} \mathrm{HPO}_{4}$ を含む $\mathrm{pH} 10.0$ の緩衝 液が使用された。

\section{$3 \cdot 5$ 濃縮時間の影響}

$\mathrm{OPPy} / \mathrm{PVP}$ 膜カーボンペースト電極上にフェノールを 濃縮する時間と酸化電流值の関係を Fig. 5 に示した. フ エノールの酸化電流は濃縮時間の増加に伴って大きくな 


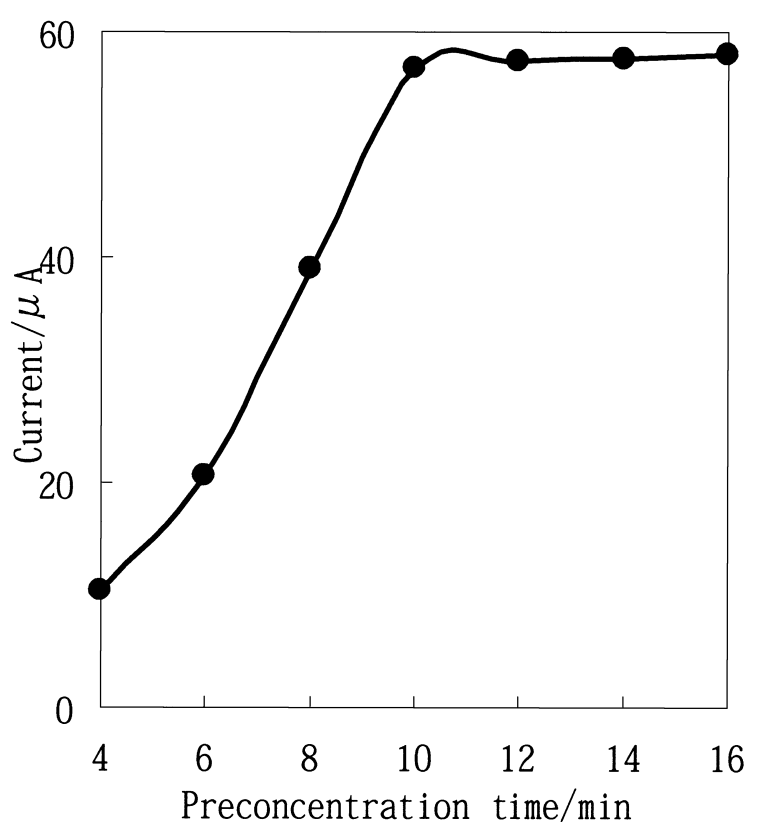

Fig. 5 The relationship between the current and the preconcentration time

る. 約 10 分間を超えると, フェノールの酸化電流の変化 はあまり観察されずに, OPPy/PVP 膜カーボンペースト 電極に濃縮されたフェノールが飽和状態になったと考えら れる.このため, 本研究ではフェノールの濃縮時間を 10 分間とした。

\section{$3 \cdot 6$ 直線性の範囲と検出限界}

$\mathrm{OPPy} / \mathrm{PVP}$ 膜カーボンペースト電極上のフェノールの 酸化電流は, フェノール濃度 $1.0 \times 10^{-6} \sim 1.0 \times 10^{-3} \mathrm{M}$ の範囲で直線性を示した。その関係は $I=1.8209+57180$ $C(I / \mu \mathrm{A}, C / \mathrm{M})$ で表現でき, 回帰係数は 0.9986 であっ た。検出限界は $1.0 \times 10^{-7} \mathrm{M}$ となった。この程度の検出 限界であれば，廃水中のフェノールの検出は充分可能であ る.

$1.0 \times 10^{-4} \mathrm{M}$ のフェノールを連続的に 10 回測定すると, その相対標準偏差は $3.1 \%$ となり，この修飾電極は比較的 良い再現性を持つことが分かった。

\section{$3 \cdot 7$ 共存物質の影響}

コークス製造工場の廃水は主にフェノール性物質であ り，この中にはフェノール，メチルフェノール及びニトロ フェノールが含まれる。 OPPy/PVP 膜カーボンペースト 電極を用いて， $1.0 \times 10^{-4} \mathrm{M}$ フェノールの測定に対し，4メチルフェノール及び 4 -ニトロフェノールの影響を調べ た。フェノルに対して 100 倍濃度の 4-ニトロフェノー ル，10 倍濃度の 4-メチルフェノールが共存しても，フェ ノール測定への影響は小さく，測定誤差はそれぞ れ $-3.9 \%$ と $+5.1 \%$ であった。

以上述べてきたように, OPPy/PVP 膜カーボンペース 卜電極はフェノールに対し非常に良い濃縮能力を持ち，選 択性と再現性が良いこと，また簡易に作製できることか ら，環境水やコークス工場の排水中のフェノール濃度測定 に使用できるものと思われる。

\section{文献}

1) C. D. Chriswell, R. C. Chang, J. S. Fritz: Anal. Chem., 47, 1325 (1975).

2) F. Bosch, G. Font, J. Mares: Analyst, 112, 1335 (1987).

3) E. Delaye, G. Bohnon, A. Baron, J. F. Drilleau: J. Chromatogr., 555, 125 (1991).

4) T. M. Anh, S. V. Dzyadevych, A. P. Soldatkin, N. D. Chien, N. J. Renault, J. M. Chovelon: Talanta, 56, 627 (2002).

5) R. Solna, S. Sapelnikova, P. Skladal, M. WintherNielsen, C. Carlsson, J. Emneus, T. Ruzgas: Talanta, 65, 349 (2005).

6) H. Wang, A. Zhang, H. Cui, D. Liu, R. Liu : Microchem. J., 59, 448 (1998).

7) H. Yi, K. Wu, S. Hu, D. Cui: Talanta, 55, 1205 (2001).

8) H. Lund, M. M. Baizer (Eds.): "Organic Electrochemistry, an Introduction and a Guide", $3^{\text {rd }} \mathrm{Ed}$., Revised and Expaned, Chap. 16 (1991), (Mercel Dekker).

9) Z. Chen, K. Okamura, T. Nagaoka: Anal. Sci., 18, 418 (2002).

10) K. Wang, B. J. Xu: Journal of Zhejiang University, 22 (3), 249 (1996).

11) Z. Chen, A. Okimoto, T. Kiyonaga, T. Nagaoka: Anal. Chem., 71, 1834 (1999). 


\title{
Determination of Phenol Using a Carbon Paste Electrode Modified with Overoxidized Polypyrrole/Polyvinylpyrrolidone Films
}

\author{
Zhidong CHEN $^{1}$ and Masashi Hojo ${ }^{2}$ \\ ${ }^{1}$ Department of Chemical Engineering \& Technology, Jiangsu Polytechnic University, Changzhou, Jiangsu, \\ China \\ ${ }^{2}$ Faculty of Science, Kochi University, 2-5-1, Akebonocho, Kochi-shi, Kochi 780 - 8520
}

(Received 25 February 2007, Accepted 13 June 2007)

\begin{abstract}
A novel method for the determination of phenol at a carbon-paste electrode coated with overoxidized polypyrrole and polyvinylpyrrolidone films (OPPy/PVP) has been developed. Phenol in a $0.1 \mathrm{M}$ KCl solution was preconcentrated during an open circuit for $10 \mathrm{~min}$, and was then determinated in a phosphate buffer $(\mathrm{pH} 10.0)$. A sensitive oxidation peak was observed at about $+0.48 \mathrm{~V}$ (vs. Ag/AgCl). The peak current was well-proportional to the phenol concentration in a very wide range from $1.0 \times 10^{-6}$ to $1.0 \times 10^{-3} \mathrm{M}$, and the detection limit was $1.0 \times 10^{-7} \mathrm{M}$. The modified electrode with high sensitivity and selectivity is easy to prepare, and can be applied to the determination of phenol in waste water.
\end{abstract}

Keywords : over-oxidized polypyrrole; polyvinylpyrrolidone; phenol determination ; modified carbon paste electrode. 